\title{
Remediation of Nickel Ion from Soil and Water Using Nano Particles of Zero-Valent Iron (nZVI)
}

\author{
GOPAL RATHOR $^{1 *}$, NEELAM CHOPRA ${ }^{1}$ and TAPAN ADHIKARI ${ }^{2}$ \\ ${ }^{1}$ Department of Chemistry, Government M.V.M. Bhopal 462 001, India. \\ ${ }^{2}$ Division of ESS, Indian Institute of Soil Science, Bhopal 462 038, India. \\ ${ }^{*}$ Corresponding author Email: gopal.rathor8@gmail.com
}

http://dx.doi.org/10.13005/ojc/330259

(Received: December 10, 2016; Accepted: January 25, 2017)

\begin{abstract}
The management of nickel contaminated soil and water is a major current environmental issue. The main reason for pollution of the environment with nickel is the use of metal complexes in industry, agriculture and household. Nickel kept under environmental pollutant category due to their toxic effects in plants, human and food. There were more methods applicable for heavy metals removal are ion-exchange, adsorption by activated carbon, carbon nanotubes or bioadsorbents, membrane filtration or electrochemical processes. Each method has its limitations, from high investment or operational costs to low removal efficiency and big volume of produced sludge. Nanotechnology offers a number of emerging techniques much more effective and less costly that could work to immobilize contaminants. In the present study, nanoparticles zero valent iron was used to nickel removal from polluted soil and water. Nanopartcles of Zero-valet Iron was synthesized in lab using bottom-up with $0.1 \mathrm{M} \mathrm{FeSO}_{4}, 0.05 \mathrm{M}$ EDTA and $0.75 \mathrm{M} \mathrm{NaBH}_{4}$ solutions. TEM, SEM, DLS, DLS zeta, XRD and BET techniques were used to characterization of $\mathrm{nZVI}$. The black coloured synthesized nanoparticles proved to have very small size (less than $100 \mathrm{~nm}$ ), zeta potential $-9.9 \mathrm{mv}$, Surface area $20.96 \mathrm{~m}^{2} / \mathrm{g}$. In this study we found that reduced the nickel content in spiked water up to $97 \%$ when the water is treated with nZVI (100 mg/10 ml of water) while in the case of spiked soil, nickel remediation was recorded nearly $85 \%$ after treatment of $n Z V I ~(100 \mathrm{mg} / 10 \mathrm{~g}$ of soil). The safely ability of iron to act as an electron donor or reducing agent.
\end{abstract}

Keywords: Nanotechnology, nZVI, Remediation, Nickel pollution, Soil and water.

\section{INTRODUCTION}

The management of nickel and other pollutant in soil and water is a major current environmental issue. Nickel is naturally occurring in surface water and soil but some actives like industrialization, urbanization, use of chemical fertilizer, pesticides and organic manures increase the nickel concentration (Alloway, 1995; Salt, 2000). Nickel is not only effect on human health as well as plants. The main toxic symptom produced by nickel is the chlorosis or yellowing of leaves usually followed by necrosis (Rathor et al., 2014). There are many toxic effects on human health, like embryo 
toxic effect, allergic reactions, nephrotoxic effects and contact dermatitis due to nickel (Menzel, 1987). There were more methods applicable for nickel removal are ion-exchange, adsorption by activated carbon, carbon nanotubes or bioadsorbents, membrane filtration or electrochemical processes. Each method has its limitations, from high investment or operational costs to low removal efficienc. In recent year, nanotechnology offers new things for management environmental pollution. Use of $n Z V I$ to remediate contaminated soil and water has received increasing amounts of attention within the last decade, primarily due to its potential for broader application, higher reactivity and cost effectiveness compared to conventional ZVI applications. The use of macro scale $Z \mathrm{VI}$ in subsurface PRBs is a well established technology for the reduction of both chlorinated hydrocarbons and toxic metals in contaminated ground water, a nZVI use exactly the same chemistry, but has advantage of having increased surface area and the rheological ability of nanoparticles to flow in the subsurface (Nurmi et al., 2005) and has been found effective for the detoxification of organic contaminants such as polychlorinated biphenyls (PCB)( He and Zhao, 2005b; Wang and Zhang, 1997). The ability of iron to act as an electron donor or reducing agent is utilized in technique known as Fenton treatment techniques, where (Hong et al., 2007).

\section{MATERIAL AND METHODS}

\section{Synthesis of $n Z V I$}

Nanoscale $\mathrm{Fe}^{0}$ particles were synthesized by adding $1.6 \mathrm{M} \mathrm{NaBH}_{4}$ in a $1.0 \mathrm{M} \mathrm{FeCl}_{3}$ solution with magnetic stirring (Wang and Zhang 1997). But the main drawback of this procedure, nanoparticles are not stable (colour change from black to yellow)

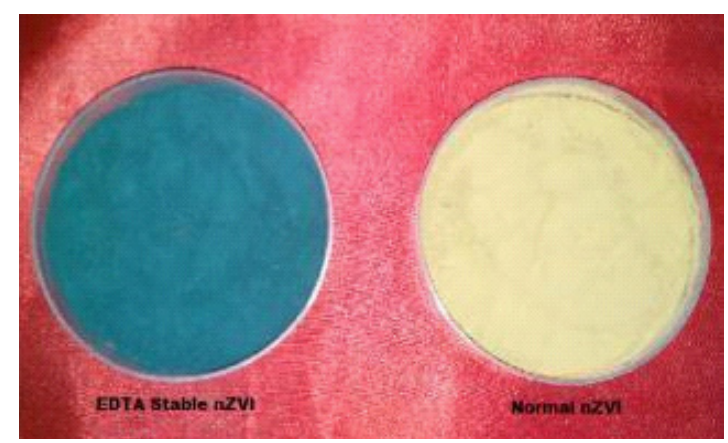

Plate-1: Photo of EDTA stable and normal nZVI (plate 1). So we followed the procedure Murad et al., 2010, in this procedure $150 \mathrm{~mL}$ of $0.1 \mathrm{M} \mathrm{FeSO}_{4}$ and $100 \mathrm{~mL}$ of $0.05 \mathrm{M}$ EDTA were mixed in a flask by using propeller mixing. The $100 \mathrm{~mL}$ of $0.75 \mathrm{M} \mathrm{NaBH}_{4}$ was added drop wise with continues staring into the mixture solution at room temperature (figure 1). Slowly the solution turned to black colour. The black coloured particles were filtered, washed trice with absolute ethanol, dried and pulverized.

\section{Characterization of $n Z \mathrm{~V} \mathbf{I}$}

The particle size, size distribution and morphology of synthesized nZVI was measured with TEM (Transmission Electron Microscope) (JEOL, 100 CX, Japan TEM instrument). The phase identification of $n Z V I$ was determined by X-ray diffraction (XRD). Zeta potential and size were identified by DLS (HORIBA Scintific). The BrunauerEmmett-Teller (BET) instrument was used for surface area measurement of sample (Model: Mumbai Surfer Ultra micropore, Tritech Instruments India Pvt.). The structural and morphological characterizations of the samples were accomplished using a SEM (scanning electron microscopy).

\section{Remediation of nickel in soil and water}

Laboratory experiments were conduct for the remediation of nickel in spiked soil and water using nZVI. The soil sample was sieved through a 2-mm sieve. Soil and water samples were spiked (levels 0, 25, 50, 75, 100 and 150 ppm) using $\mathrm{NiCl}_{2}$ salt. Lindsay and Norvell (1978) method were used for determination of available nickel in soil pre and after treatment with nZVI. In this experiment $10 \mathrm{~g}$ spiked soil was taken in a $25 \mathrm{~mL}$ of centrifuge tube then add $100 \mathrm{mg}$ of $\mathrm{nZVI}$ powder with $2 \mathrm{~mL}$ of distilled water. Sample was incubated for 7 days at $30^{\circ} \mathrm{C}$. After incubation, $20 \mathrm{~mL}$ of DTPA solution was

Table 1: Remediation of nickel spiked water using $\mathrm{nZVI}$

\begin{tabular}{|c|c|c|c|}
\hline S. No & $\begin{array}{c}\text { Initial } \\
\text { concentration } \\
\text { of } \mathrm{Ni}\left(\mathrm{mg} \mathrm{L}^{-1}\right)\end{array}$ & $\begin{array}{c}\text { Final } \\
\text { concentration } \\
\text { of } \mathrm{Ni}\left(\mathrm{mg} \mathrm{L}^{-1}\right)\end{array}$ & $\begin{array}{l}\text { Removal } \\
\text { of } \mathrm{Ni}(\%)\end{array}$ \\
\hline 1 & 25 & 0.7 & 97 \\
\hline 2 & 50 & 2.5 & 95 \\
\hline 3 & 75 & 5.2 & 93 \\
\hline 4 & 100 & 15.0 & 85 \\
\hline 5 & 150 & 24.6 & 83 \\
\hline
\end{tabular}


added and shaked for 30 minutes on shaker. After shaking centrifuge the sample for 15 minutes at $2000 \mathrm{rpm}$ and filtered. In the case of water $10 \mathrm{~mL}$ of spiked water was taken in a $25 \mathrm{~mL}$ of centrifuge tube then added $100 \mathrm{mg}$ of $\mathrm{nZVI}$ powder. Sample was incubated for 7 days at $30^{\circ} \mathrm{C}$. after incubation shaked for 30 minutes on shaker. After shaking centrifuge the sample for 15 minutes at $2000 \mathrm{rpm}$ and filtered. Filtrate samples were taken for measurement of nickel on ICP-OES (Parkin Elmer Optima 2100). The removal efficiencies of nickel with nZVI were calculated using following equation-

$$
R(\%)=\frac{C-C_{0}}{C} * 100
$$

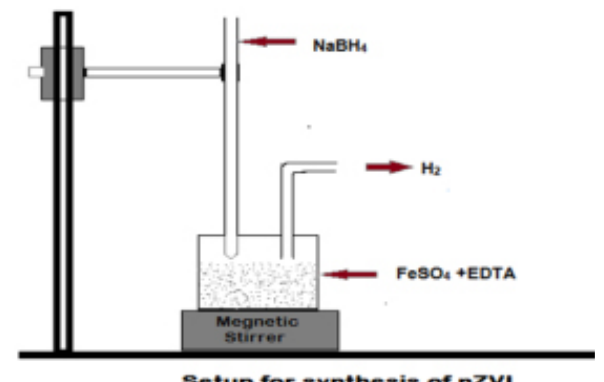

Fig. 1: Schematic diagram for synthesis of $\mathrm{nZVI}$

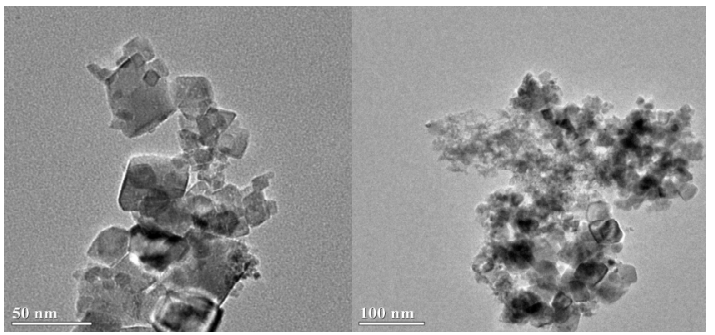

Fig. 3: TEM micrograph of $\mathrm{nZVI}$

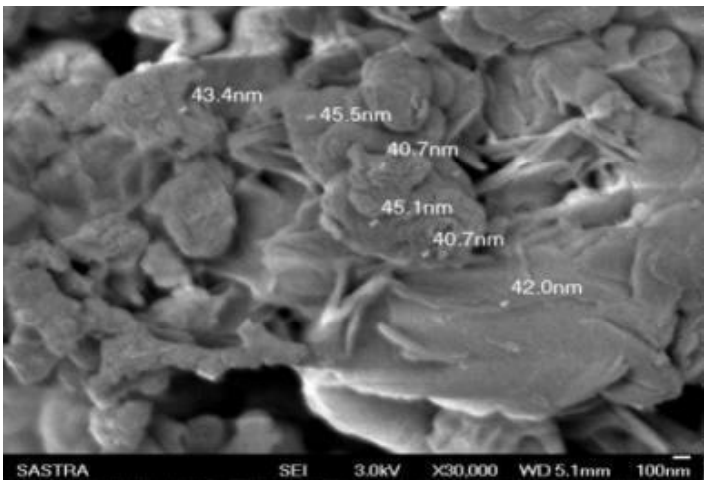

Fig. 5: SEM micrograph of $\mathrm{nZVI}$ powder
Where $R(\%)$ is the removal efficiency, $C$ and $C_{0}\left(\mathrm{mg} \mathrm{L}^{-1} \mathrm{or} \mathrm{mg} \mathrm{kg}^{-1}\right)$ are the initial and final concentration of nickel treated with $\mathrm{nZVI}$.

\section{RESULT AND DISCUSSIONS}

\section{Characterization of $\mathrm{nZVI}$}

The mean hydrodynamic diameter was around $100 \mathrm{~nm}$ (Figure 2). TEM image of particles are spherical with the size ranging from 10 to 100 $\mathrm{nm}$ in diameter (Figure 3). The zeta potential value of $n Z V I$ was recorded $-9.9 \mathrm{mv}$ (Figure 4). The SEM micrograph of $\mathrm{nZVI}$ shows that the changes in particle shapes and sizes were distinctly visible (Figure 5). Figure 6 shows that powder XRD pattern

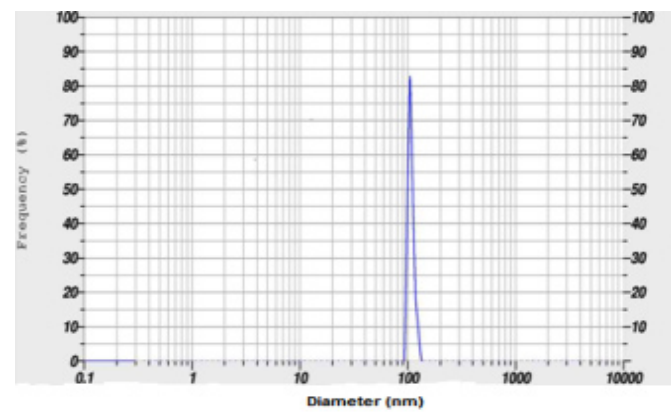

Fig. 2: N Size (DLS) of nZVI powder

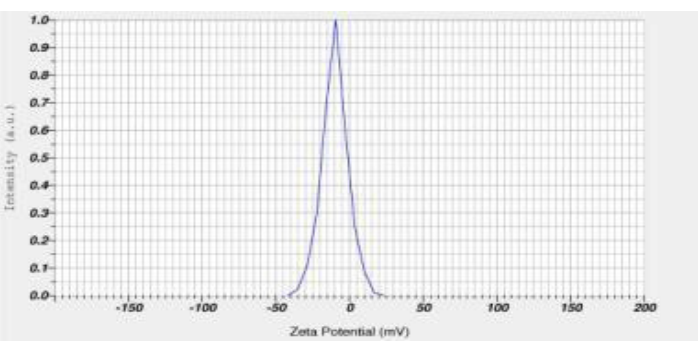

Fig. 4: Zeta potential of nZVI powder

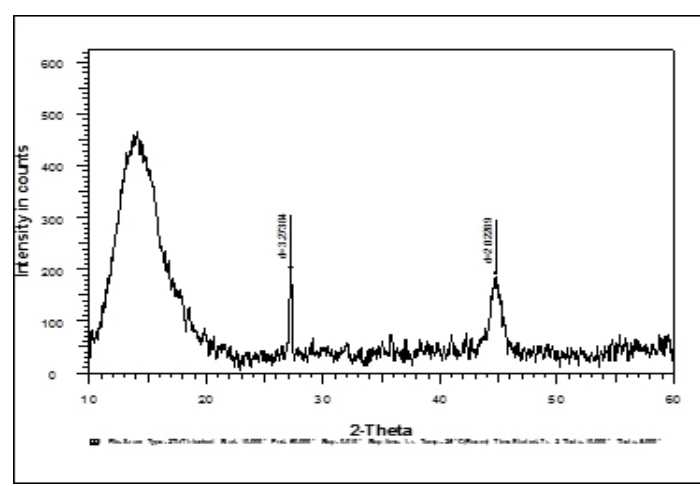

Fig. 6: XRD of $n Z V I$ powder 
Table 2: Remediation of nickel spiked soil using nZVI

\begin{tabular}{ccccc}
\hline $\begin{array}{c}\text { S. } \\
\text { No. }\end{array}$ & $\begin{array}{c}\text { Treatment } \\
\text { Ni }\left(\mathbf{m g ~ k g}^{-1}\right)\end{array}$ & $\begin{array}{c}\text { DTPA Ni } \\
\left(\mathbf{m g ~ L}^{-1}\right)\end{array}$ & $\begin{array}{c}\text { Final concentration } \\
\text { of Ni }\left(\mathbf{m g ~ L}^{-1}\right) \text { treated } \\
\text { with nZVI }\end{array}$ & $\begin{array}{c}\text { Removal } \\
\text { Ni (\%) }\end{array}$ \\
\hline 1 & 0 & 0.60 & 0.02 & 96 \\
2 & 25 & 4.90 & 0.70 & 85 \\
3 & 50 & 8.30 & 2.50 & 70 \\
4 & 75 & 9.10 & 2.80 & 69 \\
5 & 100 & 12.40 & 6.17 & 50 \\
6 & 150 & 18.70 & 12.2 & 35 \\
\hline
\end{tabular}

of $\mathrm{nZVI}$ samples under ambient conditions. The broad peak reveals the existence of an amorphous phase of iron. The characteristic broad peak at 2è of $45^{\circ}$ indicates that the zero valent iron is predominantly present in the sample. The surface area of $n Z \mathrm{VI}$ was $20.96 \mathrm{~m}^{2} / \mathrm{g}$.

\section{Remediation of nickel in soil and water}

A perusal of the data presented in table 1 revealed that the application of $n Z V I$ reduced the nickel content in spiked water up to $97 \%$. The removal efficiency of nickel in solution was recorded $51 \%$ with nZVI (Matysikova et al., 2014). Stetter et al., (2002) also studied that in the case of ground water; effective removal of nickel can be achieved using chelating ion exchange resins. In the case of spiked soil, nickel decontamination was recorded nearly $85 \%$ (Table 2). The removal efficiency was decreased with increasing the concentration of nickel in soil and water. Also the $\mathrm{nZVI}$ was used for removing of nickel from soil (Bazdanis et al., 2011). Saleem et al., (2011) found that the $74 \%$ nickel removed from low permeability soil using titanium electrode (Electrokinetic Remediation). Nickel concentration was reduced in spiked soil and water to $(250 \mathrm{mg} / 10 \mathrm{~g}$ of soil) $75-92 \%$ and (500 mg/20 ml of polluted water) 99.6\% respectively with CNPs (Rathor et al., 2013).
Zero valent iron which is very useful tool to remove heavy metal from contaminated soil and water also have been studied in different condition (Groza et al., 2009; Hojeong et al., 2008; Kakarla et al., 2008).

\section{CONCLUSION}

Nickel pollution is a very dangerous issue for environment. That nickel pollution not only affects the human health but also the quality of soil, water and plants. In this study we synthesized and characterized of $\mathrm{nZVI}$ powder and systematically investigated the removal efficiency of nickel from aqueous solution and spiked soil by varying concentration of nickel ion. This studied showed nickel contamination was removed up to $85 \%$ and $97 \%$ from contaminated soil and water respectively, with $\mathrm{nZVI}$.

\section{ACKNOWLEDGMENT}

The author would like to express their appreciations to Dr. Tapan Adhikari, Principle Scientist (PI Nanotechnology Project) and Dr. Neelam Chopra, Asst. Professor for their valuable discussion and useful suggestions. This research was supported by the Indian Institute of Soil Science (ICAR), Bhopal and Govt. Motilal Vigyan Mahavidhyalaya, Bhopal.

\section{REFERENCES}

1. Alloway, B. J.; Heavy Metal in Soils (Ed: B.J. Alloway) 2nd ed., Blackie Academic and Professional, London, 1995., 25-34,.

2. Bazdanis, G.; Komnitsas, K.; Sahinkaya, E.; Zaharaki, D., Removal of heavy metals from leachates using permeable reactive barriers filled with reactive organic/inorganic mixtures, Third International Conference on Environmental Management, Engineering, Planning and Economics, Skiathos Island, Greece, 2011.

3. Easton, D. F., Nickel and Human Health: Current Perspectives (Eds: E. Nieboer, J. O. Nriagu,) John Wiley and Sons. New York, 
1992, 603-619.

4. Groza, N.; Radulescu, R.; Panturu, E.; Filcenco-Olteanu, A.; Panturu, R. I., ZeroValent Iron Used for Radioactive Waste Water Treatment. Chemistry Bulletin "POLITEHNICA" University (Timisoara),2009, 54 (68): 1-21.

5. He, F.; Zhao, D., Application of novel stabilizers for enhanced mobility and reactivity of iron-based nanoparticles for in situ destruction of chlorinated hydrocarbons in soils, Abstracts of Papers, 230th ACS National Meeting,Washington, DC, United States, Aug. 28-Sept. 1, 2005, ENVR-077, 2005b.

6. Hojeong, K.; Honga, H. J.; Leea, Y. J.; Shinb, H. J.; Yanga, J. W., Degradation of trichloroethylene by zero-valent iron immobilized in cationic exchange membrane, Presented at the conference on Desalination and the Environment, Sponsored by the European Desalination Society, 2008, 223,. 212-220.

7. Jin, J.; Zhao, W. R.; Xu, X. H.; Hao, Z. W.; Liu,Y.; He, P.; Zhou, M.; Remediation of $\mathrm{Ni}^{2+}$ contaminated water using iron powder and steel manufacturing by products, J. Environ. Sci. (China), 2006, 18(3): 464-467.

8. Kakarla, P. K.; Andrews, T.; Greenberg, R. S.; Zervas, D. S.; Modified Fenton's processes for effective in-situ chemical oxidation laboratory and field evaluation, Remediation, 2002, 12 : 23-36.

9. Lindsay, W. L.; Norvoll, W. A.; Development of DTPA test for $\mathrm{Fe}, \mathrm{Zn}, \mathrm{Mn}$, and $\mathrm{Cu}$, Soil Sci. Soc. Ame. J.I, 1978, 42: 421- 428.

10. Matysíkova, J.; Sukopova, M.; Skorvan, O.; Holba, M.; Use of iron nanoparticles for post-treatment of metal finishing Wastewater, Nano Conference Nov $5^{\text {th }} 7^{\text {th }}$, Brno, Czech Republic, EU, 2014.

11. Menzel, D. B.; Pharmacokinetic modeling of the lung burden from repeated inhalation of nickel aerosols, Toxicology letters, 1987, 38: 33-43

12. Murad, B. A.; Mandal, B. K.; Kesarla, M. K.; Koppala, S. K.; Reddy, P. S.; Preparation of Stable Zero Valent Iron Nanoparticles using Different Chelating Agents, J. Chem. and Pharmace. Res., 2010, 2(5): 67-74.

13. Nurmi, J.T.; Trantnyek, P. G.; Sarathy, V.; Baer, D. R.; Amonette, J. E.; Pecher, K.; Wandg, C.; Linehan, J. C.; Matson, D.W.; Leepenn, R.; Driessen, M. D.; Characterization and Properties of Metallic Iron Nanoparticles: Spectroscopy, Electrochemistry and Kinetics, Envir. Scie. Tec., 2005, 39: 1221-1230.

14. Rathor, G.; Adhikari, T; Chopra, N.; Management of Nickel Contaminated Soil and Water Through the use of Carbon Nano Particles, J. Che. Biolo. Phys. Sci., 2013, 3(2): 901-905.

15. Rathor, G.; Chopra, N.; Adhikari, T.; Effect of variation in Nickel concentration on Growth of Maize plant: A comparative over view for Pot and Hoagland culture, Res. J. Che. Sci., 2014, 4(10): 30-32.

16. Saleem, M.; Chakrabarti, M. H.; Irfan, M. F.; Hajimolana, S. A., Hussain, M. A.; Diya'uddeen, B. H.; Daud, W. M. A. W.; Electrokinetic Remediation of Nickel from Low Permeability Soil, Int. J. Electrochemi. Sci., 2011, 6, 4264-4275.

17. Salt, D. E.; Phytoremediation of Contaminated Soil and Water (Eds: N. Terry, G. Banuelos) Lewis Publishers, Boca Raton, FL, 2000, 189-200.

18. Stetter, D.; Dordlemann, O.; Overath, H.; Pilot scale studies on the removal of trace metal contaminations in drinking water treatment using chelating ion-exchange resins, Water Supply, 2002, 2(1), 25-35.

19. Wang, C. B.; Zhang, W. X.; Synthesizing nanoscale iron particles for rapid and complete dechlorination of TCE and PCBs, Envir. Sci. Techn., 1997, 31, 2154-2156. 